Anim. Reprod., v.16, n.1, p.81-92, Jan./Mar. 2019

\title{
The Sertoli cell: what can we learn from different vertebrate models?
}

\author{
Nathália de Lima e Martins Lara, Guilherme Mattos Jardim Costa, André Felipe Almeida Figueiredo, \\ Luiz Renato de França ${ }^{\S}$
}

Laboratory of Cellular Biology, Department of Morphology, Federal University of Minas Gerais, Belo Horizonte, MG, Brazil.

\begin{abstract}
Besides having medical applications, comparative studies on reproductive biology are very useful, providing, for instance, essential knowledge for basic, conservation and biotechnological research. In order to maintain the reproductive potential and the survival of all vertebrate species, both sperm and steroid production need to occur inside the testis. From the approximately fifty thousand vertebrate species still alive, very few species are already investigated; however, our knowledge regarding Sertoli cell biology is quite good. In this regard, it is already known that since testis differentiation the Sertoli cells are the somatic cells in charge of supporting and orchestrating germ cells during development and full spermatogenesis in adult animals. In the present review, we highlight key aspects related to Sertoli cell biology in vertebrates and show that this key testis somatic cell presents huge and intrinsic plasticity, particularly when cystic (fish and amphibians) and non-cystic (reptiles, birds and mammals) spermatogenesis is compared. In particular, we briefly discuss the main aspects related to Sertoli cells functions, interactions with germ cells, Sertoli cells proliferation and efficiency, as well as those regarding spermatogonial stem cell niche regulation, which are crucial aspects responsible for the magnitude of sperm production. Most importantly, we show that we could greatly benefit from investigations using different vertebrate experimental models, mainly now that there is a big concern regarding the decline in human sperm counts caused by a multitude of factors.
\end{abstract}

Keywords: Sertoli cell; vertebrates; amniotes; anamniotes; spermatogenesis.

\section{Introduction}

Since testis differentiation, in all vertebrate species so far investigated the Sertoli cells are the somatic cells in charge of supporting and orchestrating germ cells during their development and full spermatogenesis in adult animals (Pudney, 1993; Hess and França, 2005; Oatley et al., 2011; Griswold, 2015; França et al., 2016). Therefore, the total number of Sertoli cells per testis, as well as their proper interactions with germ cells and the number of these cells per Sertoli cell (Sertoli cell efficiency), are the key qualitative and quantitative determinants of sperm production (Sharpe, 1994; Hess and França, 2007; Griswold, 2015; França et al., 2016). In the present review, we concisely discuss and compare the key aspects related to Sertoli cell biology in different vertebrate groups, such as anamniotes (fish and amphibians) and amniotes (reptiles, birds and mammals), where respectively cystic and non-cystic spermatogenesis are observed (França et al., 2015, 2016).

\section{Sertoli cell discovery and morphology}

The testis is the male gonad, where steroidogenesis and sperm production take place. Spermatogenesis is a highly organized process in which the germ cells go through several divisions and intricate differentiation steps, resulting in the production of the spermatozoa. This process is orchestrated mainly by the Sertoli cell that were named after Enrico Sertoli, author of the first publication reporting their existence (Sertoli, 1865; Ebner, 1888; Hess and França, 2007). In this publication, Enrico Sertoli describes their morphology "not unlike trees", including details such as their bifurcated branches of cytoplasm, the niches where germ cells fit and the large nucleolus, apart from calling them "mother cells", anticipating the comprehension of their crucial functions (Sertoli, 1865; Hess and Vogl, 2015).

Using advanced staining techniques and electron microscopy, many decades later the details of the Sertoli cells morphology and function were shown and the understanding of this complex cell's role in the testis morphophysiology have been a major topic in male reproduction research. Therefore, numerous reviews (Regaud, 1899; Elftman, 1963; Fawcett, 1975; Clermont et al., 1987; Sharpe, 1988; de Kretser, 1990; Clermont, 1993; Russell, 1993a,b; Vogl et al., 1993; Kerr, 1995; Griswold, 1998; Walker, 2003a,b; Wong and Cheng, 2009; Vogl et al., 2013; Ramaiah and Wilkinson, 2015; Griswold, 2016; França et al., 2016) and books (Russell and Griswold, 1993; Skinner and Griswold, 2005; Griswold, 2015) have been published describing the Sertoli cell morphology and functions, mostly focusing on mammals. However, due to the cystic versus non-cystic arrangement of spermatogenesis, distinct Sertoli cell characteristics are observed when comparing different vertebrate species [anamniotes (fish and amphibians) and amniotes (reptiles, birds and mammals)] (Please see Section 4 and Figure 1) (Russell and Griswold, 1993; Griswold, 1998; Hess and França, 2007; Schulz et al., 2010; França et al., 2015, 2016).

Reflecting their relationship with germ cells, in overall the Sertoli cell shape may vary according to the species and the progression of spermatogenesis. 
Considerable variations are also observed for the expression of proteins and growth factors, which also change according to the age of development and seasonality (Russell, 1993a,b; Rothbarth et al., 2001; França and Chiarini-Garcia, 2005; Hess and Vogl, 2015; França et al., 2016). Additionally, as the germ cell requirements, interactions and metabolic needs change substantially, high variations are observed on the Sertoli cell cytoplasm extension, the amount of nuclear pores, the presence and translocation of organelles and the protein expression pattern and location across the different phases of spermatogenesis (Toppari et al., 1991; França et al., 1993; Cavicchia et al., 1998; Johnston et al., 2008; Wright, 2015). To illustrate the above-mentioned variation on Sertoli cells characteristics, due to their endocytic activity in the elimination of residual bodies, an increase in the amount of lipid and lysosomes is usually observed in the Sertoli cells cytoplasm after spermiation (Ye et al., 1993; França et al., 1995; Hess and França, 2005). Structural characteristics of the Sertoli cells also varies among species, such as the heavily vacuolated nucleolus present in some ruminants (Pawar and Wrobel, 1991; Steger and Wrobel, 1994), the nucleus localization in the middle of the seminiferous epithelium in monkeys (Hess and França, 2005), the presence of CharcotBottcher cristaloids in men (Czaker, 1994; França and Chiarini-Garcia, 2005), and the presence and amount of lipid droplets and glycogen in the Sertoli cell cytoplasm (Fouquet, 1968; Russell, 1993a,b; Tedde et al., 1993; Erkan and Sousa, 2002).

\section{Proliferation and maturation}

It is widely accepted that the number of Sertoli cells per testis and the Sertoli cell efficiency (which is measured as the number of germ cells per Sertoli cell) are the main determinants of the sperm production of a given species (Sharpe, 1994; Hess and França, 2007; Griswold, 2015; França et al., 2016). In this regard, the Sertoli cell proliferation that usually ends before puberty is a crucial event for testis physiology (Lara et al., 2018b). In laboratory rodents (such as rats and mice), this proliferation occurs mainly during fetal life, reaching its maximum activity just before birth (Orth, 1982, 1993; McCoard et al., 2003; França et al., 2016). However, the postnatal Sertoli cell mitotic activity is highly variable according to the species, lasting for instance 2-3 weeks in laboratory rodents. In humans, this somatic cell proliferate during the perinatal and neonatal period, becoming quiescent for several years and having a second peak of proliferation just before puberty (Cortes et al., 1987; Sharpe et al., 2003; Tarulli et al., 2012). In a scale of months or few years, a similar pattern is also observed in pigs, primates and cattle (Gondos and Berndston, 1993; França et al., 2000; Cooke et al., 2005).

In most studied species, FSH and androgens are considered important factors that regulate Sertoli cell proliferation (Skinner and Griswold, 2005; Lara et al., 2018b). Other factors usually associated with this process are estrogens, activins, TGF-beta, BMPs, interleukins and TNFalpha (Puglisi et al., 2004; Tarulli et al., 2012; Lucas et al., 2014a,b). After the fetal and postnatal periods of mitotic divisions, which are rather variable among different species, Sertoli cells stop proliferating and start to differentiate around puberty, being therefore able to support full spermatogenesis. This maturation process correlates for instance with the initiation of meiosis, the establishment of the Sertoli cell barrier and fluid secretion/lumen formation, which are clear signs of Sertoli cells maturation (Griswold, 2015; França et al., 2016).

Based mainly in studies developed in laboratory rodents (rats and mice), thyroid hormones are considered a key factor in the regulation of Sertoli cell differentiation/maturation (Cooke et al., 2005). In these studies, it has been shown that neonatally induced hypothyroidism prolong the proliferative period and delay Sertoli cell maturation, increasing therefore their final number and, consequently, the testis size and the magnitude of sperm production (Van Haaster et al., 1992; Joyce et al. 1993; Auharek and França 2010; Lara and França, 2017). In an opposite way, hyperthyroidism accelerates Sertoli cell maturation, resulting in a smaller population of this cell in the testis, as well as smaller testis size and lower sperm production (Van Haaster et al., 1993; Cooke et al., 2005; Auharek and França, 2010). Similar results regarding thyroid hormones effects on testis size and sperm production were observed in chicken and the Nile tilapia (Kirby et al., 1996; Matta et al., 2002). However, paradoxically, in pigs thyroid hormones seem to regulate Sertoli cells in an opposite way. In this regard, postnatally induced hypothyroidism significantly decreased the number of Sertoli cells, testis size and sperm production, whereas a higher dose of thyroid hormone (T3) augmented the number of Sertoli cells per testis (Tarn et al., 1998; Silva-Jr, 2000; Klobucar et al., 2003). In bulls, no effects on Sertoli cells number were observed after the induction of neonatal hypothyroidism, whereas human studies suggested that decreased thyroid hormones might be associated to testicular enlargement (Jannini et al., 1995; Cooke et al., 2005). There is still no explanation regarding the observed inconsistencies of thyroid hormones effects among the different species of amniotes (reptiles, birds and mammals). One of the possibilities might be related to the aforementioned differences on Sertoli cell proliferation pattern. The expression of thyroid hormone receptors and/or interactions with other testis somatic cell types (i.e Leydig and peritubular myoid cells) should also not be excluded.

In relation to anamniotes, mainly due to continuous body growth, it has been shown that the Sertoli cell population is more dynamic, and that these cells remain mitotically active even after sexual maturity (Bouma and Cloud, 2005). Particularly, during spermatogenesis progression the number of Sertoli cells enveloping an individual spermatogenic cyst increases along with the germ cell number within that cyst. Interestingly, coincident with the formation of tight junctions between Sertoli cells, and similar to the establishment of puberty in mammals, usually the 
Sertoli cell number per cyst stabilizes after meiosis is complete and spermiogenesis initiates (Matta et al., 2002; Vilela et al., 2003; Schulz et al., 2005; Leal et al., 2009; França et al., 2016). As it occurs in mammals, FSH seems to be the main factor involved in Sertoli cell proliferation in anamniotes (Schulz et al., 2010, 2012; França et al., 2016). Also, as hypothyroidism increase Sertoli cell number in tilapia (Matta et al., 2002), thyroid hormones may also be important for Sertoli cell proliferation in fish (Matta et al., 2002; Morais et al., 2013). However, in contrast to mammals, thyroid hormones stimulate Sertoli cell proliferation in zebrafish (Morais et al., 2013). Recently, França et al. (2015) proposed two modes of Sertoli cell proliferation in fish. In the first, Sertoli cell proliferate to provide new niches for spermatogonial stem cells and to form new spermatogenic cysts (Morais et al., 2013; França et al., 2015). In the second mode, Sertoli cells already enveloping an existing cyst would divide, in order to accommodate the increase in the germ cell number until meiosis is complete and Sertoli cell maturation occurs (Billard and Breton, 1978; Almeida et al., 2008; França et al., 2015). An interesting aspect that could contribute to advance our understanding on Sertoli cell proliferation/maturation in fish is the observation that one Sertoli cell may be in contact with different cysts of germ cells in different phases of spermatogenesis (França et al., 2016).

In mammals, indicating the final maturation of this cell type and its capability to support full spermatogenesis is the establishment of Sertoli cell barrier, a remarkable feature that occurs around puberty (Cheng and Mruk, 2012; Griswold, 2015; Lara et al., 2018a). This barrier, observed close to the basement membrane, is formed by specialized junctional complexes between adjacent Sertoli cells and helps to protect the germ cells undergoing meiosis from an autoimmune reaction; creating therefore an immune privileged environment within the seminiferous tubules (Tung and Fritz, 1978; Francavilla et al., 2007; França et al., 2012; França et al., 2016). The main component of this barrier are tight junctions that divide the seminiferous epithelium in two compartments: basal and adluminal, where respectively early (spermatogonia and young spermatocytes) and late (more advanced spermatocytes and spermatids) germ cells are located. Due to the complex cyclic dynamics of the Sertoli cells barrier and the formation of a transient intermediate compartment, young primary spermatocytes move across these compartments without causing any damage to the junctional structure and testis physiology (Cheng and Mruk, 2012; França et al., 2012). Other components of this important barrier include gap junctions, desmosomes, and two types of adherens junctions that are testis-specific (tubulobulbar complexes and ectoplasmic specialization) (Lee and Cheng, 2004; Vogl et al., 2008; Cheng et al., 2011; Vogl et al., 2013; Lara et al., 2018a). Overall, these structural components make the Sertoli cell barrier one of the tightest in mammals (Mital et al., 2011; Cheng and Mruk, 2012).

Regarding other vertebrate groups, there are relatively few studies related to the Sertoli cell barrier, and it is already known that the junctional complexes constituents are highly variable across vertebrates (Bergmann et al., 1984; Grier, 1993, França et al., 2012). Tight junctions and desmosomes are usually observed between adjacent Sertoli cells in anamniotes (fish and amphibians), and the barrier is present after meiosis is complete and the cyst is composed by early spermatids, the haploid cells (Pudney, 1993; McClusky, 2006; Batlouni et al., 2009; Schulz et al., 2010; França et al. 2012). However, a study in zebrafish showed that lanthanum, a tracer widely used to investigate barrier effectiveness, is never observed in the seminiferous tubule lumen, even when there is no functional barrier present (Leal et al., 2009). Similar to mammals, in reptiles and birds the barrier seems to be formed immediately after the onset of meiosis; however, there is still little information regarding its composition and structure (Bergmann et al., 1984; Bergmann and Schindelmeiser, 1987; Gribbins, 2011; Cheng and Mruk, 2012; Ahmed et al., 2016).

\section{The transition region}

The dogma that the adult Sertoli cells population constitutes a terminally differentiated population in mammals has been challenged by several recent studies (Hayrabedyan et al., 2012; Haverfield et al., 2015; Figueiredo et al., 2016; França et al., 2016). Therefore, the possible existence of a progenitor Sertoli cell has been strengthened by new evidences raised from sexually mature laboratory rodent models, indicating that the transition region, where the seminiferous tubules connect to the rete testis, could be a specific area for immature Sertoli cells (Tarulli et al., 2013; Figueiredo et al., 2016; Kulibin and Malolina, 2016). This assumption is supported mainly by current molecular observations showing that a subpopulation of Sertoli cells within the transitional region are mitotically active (BrdU-positive; Cyclin-D1-positive; Ki-67positive) and that they do not express typical differentiated Sertoli cells markers such as the transcription factor GATA-4 and the androgen receptor (Tarulli et al., 2013; Aiyama et al., 2015; Figueiredo et al., 2016; Kulibin and Malolina, 2016). Moreover, it has already been described that the adult Sertoli cells population is not morphologically homogeneous. In this particular aspect, the transition region presents modified Sertoli cells that exhibit features that resemble undifferentiated Sertoli cells, such as the presence of more ovoid nucleus, with less indentations, smaller nucleolus and more peripheral heterochromatin (Dym, 1974; Osman, 1978; Nykänen, 1979). More recently, it has been shown that these modified Sertoli cells divide in culture and are able to form colonies and generate cord-like structures (Kulibin and Malolina, 2016). Because this particular area of mammalian testis also contains spermatogonial stem cells, it has been suggested that the transition region might be an area where the seminiferous tubules continues to grow in sexually mature individuals (Tarulli et al., 2013; Aiyama et al., 2015; Figueiredo et al., 2016). Moreover, this assumption is corroborated by new findings 
indicating that the transition region is a site where seminiferous tubules are originally formed (Malolina and Kulibin, 2017).

Similar to horses and showing a testis gradient during postnatal testis development, in pigs the testis parenchyma grows asynchronously, starting its maturation nearby the intermediate and the central (transitional) area, where the testis mediastinum and the rete testis are located (Avelar et al., 2010). Moreover, resembling sexually mature laboratory rodents, Sertoli cell mitotic activity in pubertal pigs was higher in the transitional region, which is probably a primary site of seminiferous tubules growth in length. In some teleost orders, there are also evidences of the existence of functionally different testicular regions. For instance, once this specific area presents restricted distribution of proliferative Sertoli cells associated with immature spermatogonia, in perciform fish it was demonstrated that the distal region of the seminiferous tubules, nearby the tunica albuginea (blind end region), might be the source of new spermatogenic cysts formation (Schulz et al., 2005). Considering that the above-mentioned region present immature Sertoli cells exhibiting high proliferative potential, one could hypothesize the existence of stem Sertoli cells, an important aspects that still needs further investigation.

It is interesting to mention that in some invertebrate species, such as flies and nematodes, the germline stem cell niche is located at the terminal end of the tubular aspect of the gonads. Therefore, in this location, undifferentiated spermatogonial cells are steadily maintained (de Cuevas and Matunis, 2011; Aiyama et al., 2015). Another important aspect regarding the germline stem cell niche in these invertebrates is the presence of proliferative somatic cyst progenitor cells (similar to the transition region in mammals?), which produce distally somatic cyst cells that support the development and differentiation of germ cells (Dansereau and Lasko, 2008). Therefore, there are some evidences indicating the existence of a stem Sertoli cell pool, which could be a well-conserved feature during evolution.

\section{Relationship between Sertoli and germ cells}

\section{Cystic vs Non-Cystic spermatogenesis}

The maintenance of continuous sperm production throughout life in males is very complex and the fine regulation (protein synthesis and signaling) of spermatogenesis is under constant investigation (Wong and Cheng, 2009; Ramaiah and Wilkinson, 2015; Yang and Oatley, 2015; França et al., 2016; Griswold, 2016). In this context, although showing particularities among different vertebrate groups, the interactions between Sertoli and germ cells is crucial for the development and completion of spermatogenesis (Hess and França, 2007). In amniotes (reptiles, birds and mammals), a single and non-dividing Sertoli cell supports the development of different germ cells at the same time (non-cystic pattern of spermatogenesis) (Fig. 1; Russell and Griswold, 1993; França et al., 2015). In particular, at their different areas/regions the Sertoli cells present the following contacts/functions: i) regulate spermatogonia self-renew or differentiation in the basal compartment of the seminiferous epithelium (de Rooij, $2001)$; ii) create contact with spermatocytes on its lateral side, regulating the meiotic process from the duplication of DNA content to the formation of spermatids (Russell, 1977); iii) interact specifically with spermatids in the adluminal/apical portions, regulating their morphology, the reabsorption of residual bodies and controlling spermiation (Meistrich and Hess, 2013).

Different from the seminiferous epithelium organization cited above, in fish and amphibians (anamniotes) the cystic type of spermatogenesis is observed (Figure 1; França et al., 2015). In these vertebrate groups, spermatogenic cysts are formed when Sertoli cells surround the type A spermatogonia. From this point, Sertoli cells synchronously coordinate the development of these cells until they differentiate into sperm (Schulz et al., 2010, França et al., 2015). Thus, in this arrangement, a histological testis section is composed of different spermatogenic cysts, i.e., distinct units of germ cells in the same stage of development enveloped by groups of Sertoli cells (Leal et al., 2009). It is believed that in this cystic organization the Sertoli cells are more efficient, meaning that more germ cells can be supported by Sertoli cells during their development, allowing a higher sperm production (França et al., 2015). Moreover, it is hypothesized that this cystic structure allows the concentration of specific factors required for each phase of spermatogenesis (spermatogonial, spermatocitary, and spermiogenic), resulting in lower germ cell apoptosis (Vilela et al., 2003; França et al., 2015).

As it was already mentioned, due to continuous testis growth during adulthood, another characteristic already described in cystic spermatogenesis is the capacity of Sertoli cells to divide in adult animals, where Sertoli cells are observed proliferating mainly when they are in contact with mitotically active spermatogonia and in association with spermatocytes (França et al., 2015). Although there is still no proof regarding the existence of Sertoli stem cell in fish testis, some authors believe in the existence of a stem cell population, giving rise to somatic Sertoli cells (Morais et al., 2013; França et al., 2015). 

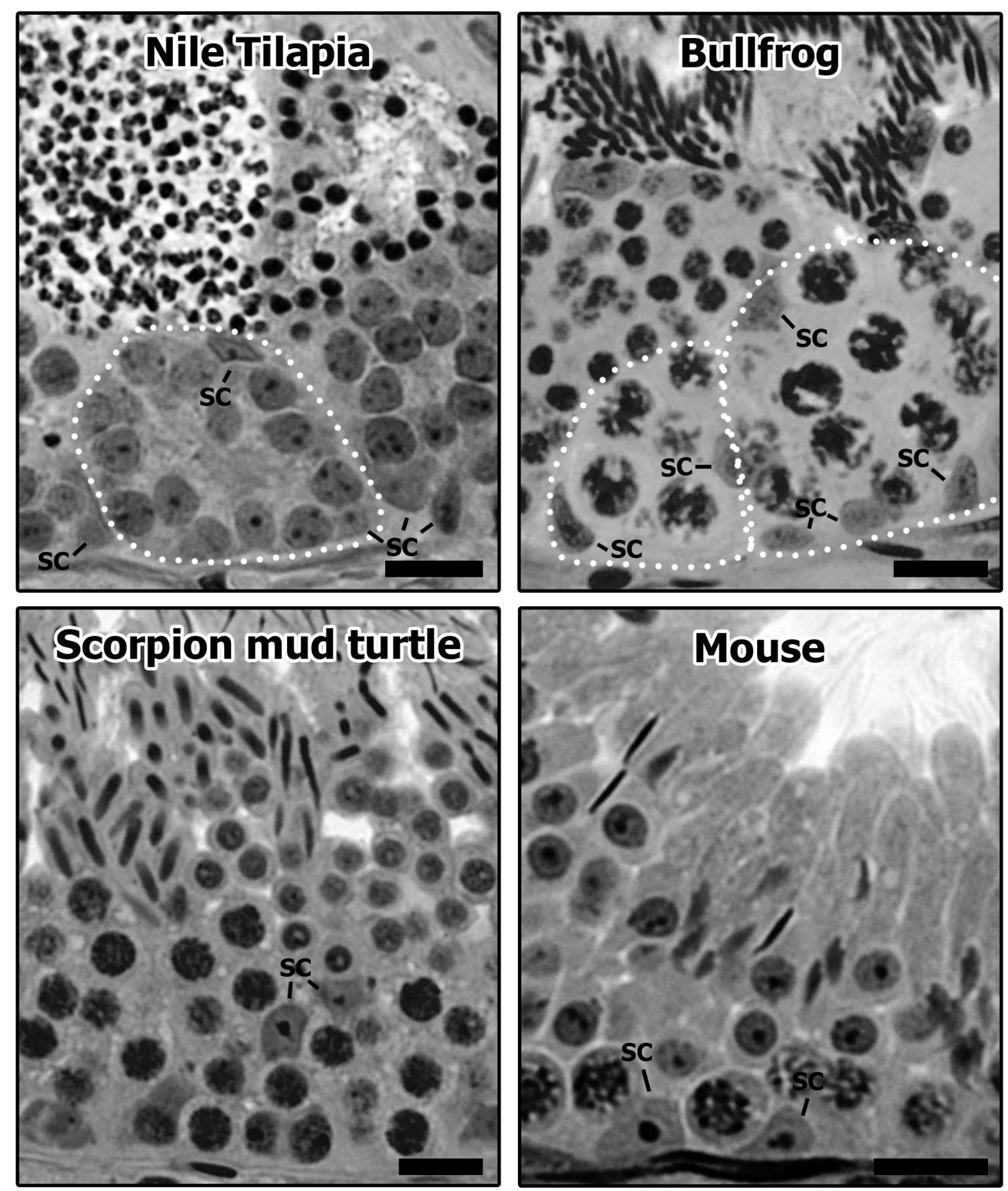

Figure 1. Histological sections from the seminiferous epithelium in different vertebrate species presenting cystic [Nile Tilapia (Oreochromis niloticus) and bullfrog (Lithobates catesbeianus)] or non-cystic [Scorpion mud turtle (Kinosternon scorpioides) and mouse (Mus musculus)] spermatogenesis arrangements. As it can be observed, the germ cell clones in the cystic arrangement are completely enveloped by the Sertoli cells (SC; white dotted lines), whereas in non-cystic arrangement one single Sertoli cell contacts several different germ cell types, despite exhibiting conspicuous structural polarity. Bars $=15 \mu \mathrm{m}$.

\section{Spermatogonial stem cell's niche}

The Sertoli cells play a key role in the functional regulation of spermatogonial stem cells niche, where other somatic testicular cells (Leydig, peritubular myoid cells and macrophages), extracellular matrices and soluble factors actively participate in the complex interaction/signaling with these stem germ cells (Chiarini-Garcia et al., 2001; Oatley and Brinster, 2012). In this microenvironment, depending on the stimulus, a balance between self-renewal and differentiation factors regulates the fate of these cells that are capable of self-renewal, differentiation and/or entering into apoptosis (Oatley et al., 2011). Acting through Sertoli cells, the glial cell-line derived neutrophic factor (GDNF) and fibroblast growth factor 2 (FGF2) are among the several factors considered important for the regulation of spermatogonial stem cells niche (Tadokoro et al., 2002; El Ramy et al., 2005; Simon et al., 2007; Chen and Liu, 2015; Chen et al., 
2016; Potter and DeFalco, 2017). In this particular aspect, the total number of Sertoli cells per testis determine the number of available spermatogonial stem cell niches and, consequently, these somatic cells dictates the magnitude of sperm production capacity (Oatley et al., 2011).

Nowadays, two types of spermatogonial stem cell niche are being proposed. In the first type, called closed niche, these undifferentiated cells are concentrated in a particular testicular parenchyma region; whereas in the second type, called opened niche, spermatogonia present a specific distribution inside the seminiferous tubules (Aiyama et al., 2015; Yoshida, 2016). In mammals, recent data have demonstrated that the transition region between seminiferous tubules and the rete testis is the closed niche area. The Sertoli cells in this region produce high amount of GDNF, maintaining the neighboring spermatogonia in an undifferentiated state (Aiyama et al., 2015). Using different species models, several studies have demonstrated that spermatogonial stem cells are usually located in the seminiferous tubules area facing blood vessels of the testis interstitial compartment. It is speculated that FSH, coming from the blood vessels, stimulates the GDNF synthesis of surrounding Sertoli cells (de Rooij, 2009).

In fish, the distribution of spermatogonia along the testis parenchyma present a very high variation. For example, similar to mammals, in tilapias the closed and opened niche are normally observed and a restricted spermatogonial distribution (closed niche) is characterized by the presence of spermatogonial stem cells that are located in the distal blind end area of the seminiferous tubules nearby the tunica albuginea (Vilela et al., 2003; Lacerda et al., 2014). However, further studies are still necessary to investigate whether the secretion of GDNF is increased in this region. Also, as it occurs in mammals, in tilapias an unrestricted distribution of undifferentiated/stem spermatogonial cells is observed and these cells are frequently observed in regions of the seminiferous tubules that are facing the blood vessels located in the intertubular compartment (Lacerda et al., 2014).

Because it allows a broad view of testis function, comparative reproductive biology studies are a powerful tool. In these comparative investigations, it was found that typical proteins that are expressed by undifferentiated spermatogonia in mammals, such as OCT4, NANOS2, PLZF and GFRA1, are also expressed in some fish species already investigated (Lacerda et al., 2014). The GFRA1 is a membrane receptor involved in spermatogonial self-renewal and its ligand (GDNF), the most extensively studied niche factor, is produced by Sertoli cells. Recent studies have demonstrated that GDNF can promote high proliferation of spermatogonial stem cells in vitro in mammals and fish (Aponte et al., 2008; Gautier et al., 2014). The secretion of GDNF by Sertoli cells is cyclic and, in mammals, coincident with the differentiation of spermatogonial stem cells to type A differentiated spermatogonia that are committed to spermatogenesis, the lowest values of this peptide are found in stages near spermiation
(Johnston et al., 2011). Therefore, this Sertoli cell regulation ensures a proper gem cell homeostasis and regulates the germ cell density observed in the seminiferous epithelium. Other important factors produced by Sertoli cells are leukemia inhibitory factor (LIF) and WNT5A, essential peptides that promote spermatogonial stem cell survival (Oatley and Brinster, 2012; França et al., 2016).

The possible role of different cells in regulating spermatogonial stem cell niche can be observed investigating different animal models, with peculiar testis parenchyma cytoarchitecture. For instance, because differentiated spermatogonia was found preferentially facing Leydig cells cords, studies in the collared peccary allowed to demonstrate that products from Leydig cells, probably androgens, act as a spermatogonial stem cells pro-differentiation factor (Campos-Junior et al., 2012). In the scorpion mud turtle testis, spermatogonial stem cells were located close to lymphatic vessels and blood vessels (Costa et al., 2018). In horses, these stem cells were located far from the connective tissue (Costa et al., 2012), whereas in chinchilla more spermatogonial stem cells are produced after the establishment of puberty, leading to a gradual and striking increase in Sertoli cell efficiency and sperm production after puberty (Leal and França, 2009).

Spermatogenic efficiency

The relative mass of tubular compartment in the testis determines the space devoted to sperm production (Hess and França, 2007). Thus, in general, species with high proportion of seminiferous tubules present high sperm production and, besides the influence of Sertoli and germ cell factors, the number of Sertoli cells per testis is considered one of the most important determinant of the magnitude of sperm production (Cooke et al., 2005; Hess and França, 2007; Lara et al., 2018b). In another important aspect, Sertoli cells show distinct capacities to support germ cell development and each Sertoli cell is able to support a relatively fixed, species-specific, number of germ cells. For instance, whereas chinchilla Sertoli cell can support 14 spermatids, each human Sertoli cell is able to support only 3 spermatids, resulting respectively in a huge difference in daily sperm production per testis gram ( $\sim 60$ vs $4-4.5$ million) between these species (Hess and França, 2007; Lara et al., 2018b). The size of the Sertoli cells and, as a consequence, the space that they occupy in the seminiferous epithelium is another important factor to be considered. Species with reduced Sertoli cells occupancy in the seminiferous epithelium, such as mice $(\sim 15 \%)$, present higher Sertoli cell and spermatogenic efficiencies when compared to humans, whose Sertoli cells show high occupancy $(\sim 40 \%)$ in the seminiferous epithelium (Hess and França, 2007).

In relation to the germ cells, the number of differentiated spermatogonial generations, which is phylogenetically determined, is also crucial in determining the magnitude of sperm production. For example, in vertebrates the number of spermatogonial generations varies from around ten in fish to two in humans (França et al., 2016). Additionally, particularly 
in mammals, germ cell loss, which is quite frequent during the spermatogonial (density-dependent regulation) and meiotic (DNA damage) phases of spermatogenesis, also significantly influences the total sperm output (Russell et al., 2002; Shaha et al., 2010; Aitken et al., 2011; Murphy and Richburg, 2014). The spermatogenic cycle length, which is controlled by the germ cell genotype (França et al., 1998), is another key factor in determining the efficiency of spermatogenesis (Hess and França, 2007). Considering the majority of the mammalian species already investigated, each spermatogenic cycle lasts about 9 to 12 days, whereas the total duration of spermatogenesis (that takes approximately $\sim 4.5$ cycles) lasts approximately 40 to 54 days. The faster the cell differentiation occurs from spermatogonia to spermatozoa, the higher the daily sperm production is. Particularly in humans, another factor that contributes to the lower sperm production is the quite long duration ( $\sim 70$ days) of spermatogenesis (Hess and França, 2007). In fish, the duration of spermatogenesis is very short and is influenced by the water temperature (Egami and Hyodo-Taguchi, 1967; Billard, 1990; Shimizu, 2003; Vilela et al., 2003; Nóbrega et al., 2009), meaning that higher temperature accelerates germ cells pace during spermatogenesis (Vilela et al., 2003; Lacerda et al., 2006; Alvarenga and França, 2009; Nóbrega et al., 2009).

During evolution, considering the different vertebrates groups, spermatogenic efficiency continually reduces and this characteristic is highly associated with the Sertoli cell support capacity, which decreases from around 100-150 (in fish) to 3 (in humans) spermatids for each Sertoli cell (França et al., 2015). In general, the support capacity of this cell in anamniotes is at least 10 times higher than that observed in mammals (França et al., 2015). Once more, these findings reinforce that Sertoli cell efficiency is critically important in determining the magnitude of sperm production (Hess and França, 2007), and claim our attention to the fact that perhaps in a near future humans will not produce sperm anymore.

\section{Sertoli-Germ cell junctions}

Interactions among testicular cells, in particular between Sertoli and germ cells, are crucial to maintain and regulate spermatogenesis in a very coordinated and organized manner, providing all the necessary structural and nutritional support for the developing germ cells (França et al., 2016; Cheng and Mruk, 2015; Lara et al., 2018a). Therefore, on its basal side Sertoli cells contact spermatogonia through adherens junctions, guiding their homing, niche and colonization (Lara et al., 2018a). In Chinese soft-shelled turtle, extensive adherens junctions were also observed between Sertoli and germ cells during active spermatogenesis, preventing the sloughing of germ cells from the epithelium (Ahmed et al., 2016). Desmosomes and gap junctions are also observed contacting adjacent germ cells, such as spermatocytes and early spermatids. At their adluminal aspect, Sertoli cells contact elongated spermatids through ectoplasmatic specialization, organizing the movement of these haploid cells as well as their release during spermiation (Cheng and Mruk, 2012; Lara et al., 2018a). Different from mammals, ectoplasmic specializations in fish seem to occur only in species with elongated spermatozoa, and this observation lead us to believe that this specialization has a role in the process of spermatid elongation (Batlouni et al., 2009). Probably being involved in the maturation of spermatids and similar to mammals, tubulobulbar complexes were described in repiles (Ahmed et al., 2016).

Present between Sertoli cell and germ cells, intercellular channels composed of gap junctions are essential to maintain the metabolic coupling and cell signaling. One of the most studied constitutive protein of the gap junction is connexin 43 (Kidder and Cyr, 2016). In humans (Defamie et al. 2003) and rats (Batias et al. 2000), connexin 43 is observed in Sertoli, spermatogonia and spermatocytes cells, which suggests an accurate communication among these cells. Similarly, in catfish (Pseudoplatystoma fasciatum) connexin 43 was observed in Sertoli cells and inside the germinal cysts containing spermatogonia and primary spermatocytes (Batlouni et al. 2005). In both fish and mammals, the expression of connexin 43 in Sertoli cells varies according to the stage of germ cell development, suggesting that a particular group of germ cells can modulate this protein expression in somatic cells (Pointis et al., 2010). However, in rainbow trout testis connexin 43 is temporally expressed in some specific spermatogenic cysts (de Montgolfier et al., 2007), whereas in guinea pig and mink this protein seems to play a role during the translocation of early spermatocytes into the adluminal compartment (Pelletier, 1995).

\section{Concluding remarks}

Although most available studies are focused on few mammalian species, particularly laboratory rodents, in this review we attempted to highlight and discuss several key aspects related to Sertoli cell biology in vertebrates. From the several topics and parameters evaluated, we can observe that, in order to accomplish their key functions in supporting the development of full spermatogenesis across vertebrates, Sertoli cells present huge and intrinsic plasticity, especially when cystic and non-cystic spermatogenesis is compared. In particular, besides the importance of knowing the regulation of Sertoli cells functions, the better understanding of the fine mechanisms related to Sertoli cell proliferation and efficiency, as well as for spermatogonial stem cell niche regulation, would significantly improve our knowledge that could be applied for instance to conservation and biotechnological approaches. Importantly, we would also greatly benefit from investigations using different experimental models, in which we could address for instance the intricate relationship between Sertoli and germ cells, mainly now that there is a big concern regarding the decline in human sperm counts caused by a multitude of factors. 


\section{References}

\begin{abstract}
Ahmed N, Yufei H, Yang P, Muhammad Yasir W, Zhang Q, Liu T, Hong C, Lisi H, Xiaoya C, Chen Q. 2016. Cytological study on Sertoli cells and their interactions with germ cells during annual reproductive cycle in turtle. Ecol Evol, 6:4050-4064.
\end{abstract}

Aitken RJ, Findlay JK, Hutt KJ, Kerr JB. 2011. Apoptosis in the germ line. Reproduction, 141:139-150. Aiyama Y, Tsunekawa N, Kishi K, Kawasumi M, Suzuki H, Kanai-Azuma M, Kurohmaru M, Kanai Y. 2015. A niche for GFR $\alpha 1$-positive spermatogonia in the terminal segments of the seminiferous tubules in hamster testes. Stem Cells, 33:2811-2824.

Almeida FF, Kristoffersen C, Taranger GL, Schulz RW. 2008. Spermatogenesis in Atlantic cod (Gadus morhua): a novel model of cystic germ cell development. Biol Reprod, 78:27-34.

Alvarenga ER, França LR. 2009. Effects of different temperatures on testis structure and function, with emphasis on somatic cells, in sexually mature Nile tilapias (Oreochromis niloticus). Biol Reprod, 80:537544.

Aponte PM, Soda T, Teerds KJ, Mizrak SC, van de Kant HJ, de Rooij DG. 2008. Propagation of bovine spermatogonial stem cells in vitro. Reproduction, 136:543-557.

Auharek SA, França LR. 2010. Postnatal testis development, Sertoli cell proliferation and number of different spermatogonial types in C57BL/6J mice made transiently hypo- and hyperthyroidic during the neonatal period. J Anat, 216:577-588.

Avelar GF, Oliveira CFA, Soares JM, Silva IJ, Dobrinski I, Hess RA, França LR. 2010. Postnatal somatic cell proliferation and seminiferous tubule maturation in pigs: a non-random event Theriogenology, 74, 11-23.

Batias C, Siffroi JP, Fenichel P, Pointis G, Segretain D. 2000. Connexin43 gene expression and regulation in the rodent seminiferous epithelium. $J$ Histochem Cytochem, 48:793- 805.

Batlouni SR, Carreno FR, Romagosa E, Borella MI 2005. Cell junctions in the germinal epithelium may play an important role in spermatogenesis of the catfish P. fasciatum (Pisces, Siluriformes). J Mol Histol, 36:97110.

Batlouni SR, Nóbrega RH, França LR. 2009. Cell junctions in fish seminiferous epithelium. Fish Physiol Biochem, 35:207-217.

Bergmann M, Schindelmeiser J. 1987. Development of the blood-testis barrier in the domestic fowl (Gallus domesticus). Int J Androl, 10:481-488.

Bergmann M, Schindelmeiser J, Greven H. 1984. The blood-testis barrier in vertebrates having different testicular organization. Cell Tissue Res, 238:145-150.

Billard R, Breton B. 1978. Rhythm of reproduction in teleost fish. In Thorpe JE (Ed.). Rhythmic Activity of Fishes. New York: Academic Press. pp. 31-53.

Billard R. 1990. Spermatogenesis in teleost fish. In Lamming GE (Ed.). Reproduction in the male. Churchill: Livingstone. pp. 183-212.

Bouma J, Cloud JG. 2005. Sertoli cell biology in fishes and amphibians. In Griswold MD, Skinner MK (Eds.). Sertoli Cell Biology. San Diego: Elsevier Academic Press. pp. 71-80.

Campos-Junior PH, Costa GM, Lacerda SM, Rezende-Neto JV, de Paula AM, Hofmann MC, França LR. 2012. The spermatogonial stem cell niche in the collared peccary (Tayassu tajacu). Biol Reprod, $86: 155,1-10$.

Cavicchia JC, Sacerdote FL, Morales A, Zhu BC. 1998. Sertoli cell nuclear pore number changes in some stages of the spermatogenic cycle of the rat seminiferous epithelium. Tissue Cell, 30:268-273.

Chen SR, Liu YX. 2015. Regulation of spermatogonial stem cell self-renewal and spermatocyte meiosis by Sertoli cell signaling. Reproduction, 149:R159-167.

Chen LY, Willis WD, Eddy EM. 2016. Targeting the GDNF gene in peritubular myoid cells disrupts undifferentiated spermatogonial cell development. Proc Natl Acad Sci USA, 113:1829-1834.

Cheng CY, Wong EW, Lie PP, Li MW, Mruk DD, Yan HH, Mok KW, Mannu J, Mathur PP, Lui WY, Lee WM, Bonanomi M, Silvestrini B. 2011. Regulation of blood-testis barrier dynamics by desmosome, gap junction, hemidesmosome and polarity proteins: An unexpected turn of events. Spermatogenesis, 1:105-115.

Cheng CY, Mruk DD. 2012. The blood-testis barrier and its implications for male contraception. Pharmacol Rev, 64:16-64.

Cheng CY, Mruk DD. 2015. Biochemistry of Sertoli cell/germ cell junctions, germ cell transport, and spermiation in the seminiferous epithelium. In Griswold md (Ed.). Sertoli cell. Oxford: Elsevier Academic Press. pp. 333-383.

Chiarini-Garcia H, Hornick JR, Griswold MD, Russell LD. 2001. Distribution of type A spermatogonia in the mouse is not random. Biol Reprod, 65:1179-1185

Clermont Y. 1993. Introduction to the Sertoli cell. In Russell LD, Griswold MD (Eds.). The Sertoli Cell. Clearwater, FL: Cache River Press. pp. xxi-xxv.

Clermont Y, Morales C, Hermo L. 1987. Endocytic activities of Sertoli cells in the rat. Ann NY Acad Sci, 513:1-15.

Cooke PS, Holsberger DR, França LR. 2005. Thyroid hormone regulation of Sertoli cell development. In Griswold MD, Skinner MK (Eds.). Sertoli Cell Biology. San Diego: Elsevier Academic Press. pp. 217-226.

Cortes D, Muller J, Skakkebaek NE. 1987. Proliferation of Sertoli cells during development of the human testis assessed by stereological methods. Int $J$ Androl, 10:589-596.

Costa GM, Avelar GF, Rezende-Neto JV, CamposJunior PH, Lacerda SM, Andrade BS, Thomé RG, Hofmann MC, França LR. 2012. Spermatogonial stem cell markers and niche in equids. PLoS One, 7:e44091.

Costa GMJ, Sousa AL, Figueiredo AFA, Lacerda SMSN, França LR. 2018. Characterization of spermatogonial cells and niche in the scorpion mud turtle (Kinosternon scorpioides). Gen Comp Endocrinol. Doi: 10.1016/j.ygcen.2018.06.019.

Czaker R. 1994. Ultrastructural study of an unusual 
crystal- loid in the Sertoli cells of the bull. J Submicrosc Cytol Pathol, 26:313-317.

Dansereau DA, Lasko P. 2008. The development of germline stem cells in Drosophila. Methods Mol Biol, 450:3-26.

de Cuevas M, Matunis EL. 2011. The stem cell niche: lessons from the Drosophila testis. Development, 138:2861-2869.

de Kretser DM. 1990. Germ cell-Sertoli cell interactions. Reprod Fertil Dev, 2:225-235.

de Montgolfier B, Dufresne J, Letourneau M, Nagler JJ, Fournier A, Audet C, Cyr DG. 2007. The expression of multiple connexins throughout spermatogenesis in the rainbow trout testis suggests a role for complex intercellular communication. Biol Reprod, 76:2-8.

de Rooij DG. 2001. Proliferation and differentiation of spermatogonial stem cells. Reproduction, 121:347-354.

de Rooij DG. 2009. The spermatogonial stem cell niche. Microsc Res Tech, 72:580-585.

Defamie N, Berthaut I, Mograbi B, Chevallier D, Dadoune JP, Fenichel P, Segretain D, Pointis G 2003. Impaired gap junction connexin43 in Sertoli cells of patients with secretory azoospermia: a marker of undifferentiated Sertoli cells. Lab Invest, 83:449-456.

Dym M. 1974. The fine structure of monkey Sertoli cells in the transitional zone at the junction of the seminiferous tubules with the tubuli recti. Am J Anat, 140:1-25.

Ebner V. 1888. Zur Spermatogenese bei den S€augethieren. Arch Mikr Anat, 31:236-291.

Egami N, Hyodo-Taguchi Y. 1967. An autoradiographic examination of rate of spermatogenesis at different temperatures in the fish, Oryzias latipes. Exp Cell Res, 47:665-667.

Elftman H. 1963. Sertoli cells and testis structure. Am J Anat, 113:25-33.

El Ramy R, Verot A, Mazaud S, Odet F, Magre S, Le Magueresse-Battistoni B. 2005. Fibroblast growth factor (FGF) 2 and FGF9 mediate mesenchymalepithelial interactions of peritubular and Sertoli cells in the rat testis. J Endocrinol, 187:135-147.

Erkan M, Sousa M. 2002. Fine structural study of the spermatogenic cycle in Pitar rudis and Chamelea gallina (Mollusca, Bivalvia, Veneridae). Tissue Cell, 34:262-272.

Fawcett DW. 1975. Ultrastructure and function of the Sertoli cell. In Hamilton DW, Greep RO (Eds.). Handbook of Physiology. Washington, DC: American Physiology Society. pp. 21-55.

Figueiredo AFA, França LR, Hess RA, Costa GMJ. 2016. Sertoli cells are capable of proliferation into adulthood in the transition region between the seminiferous tubules and the rete testis in Wistar rats. Cell Cycle, 15, 2486-2496.

Fouquet JP. 1968. Infrastructural study of the glycogen cycle in the Sertoli cells of the hamster. C R Acad Sci Hebd Seances Acad Sci D, 267:545-548.

Francavilla F, Santucci R, Barbonetti A, Francavilla S. 2007. Naturally occurring antisperm antibodies in men: interference with fertility and clinical implications. An update. Front Biosci, 12:2890-2911.
França LR, Auharek SA, Hess RA, Dufour JM, Hinton BT. 2012. Blood-Tissue Barriers: Morphofunctional and immunological aspects of the blood-testis and blood-epididymal barriers. In Cheng CY (Ed.). Biology and Regulation of Blood Tissue Barriers. Landes Bioscience and Springer Science. pp.237-259.

França LR, Chiarini-Garcia H. 2005. Sertoli cell. In Carvalho HF, Collares-Buzato CB (Eds.). Cells, A multidisciplinar approach [in Portuguese]. Barueri: Manole. pp. 302-324

França LR, Ghosh S, Ye SJ, Russell LD. 1993. Surface and surface-to-volume relationships of the Sertoli cell during the cycle of the seminiferous epithelium in the rat. Biol Reprod, 49:1215-1228.

França LR, Hess RA, Cooke PS, Russell LD. 1995. Neonatal hypothyroidism causes delayed Sertoli cell maturation in rats treated with propylthiouracil: evidence that the Sertoli cell controls testis growth. Anat Rec, 242:57-69.

França LR, Hess RA, Dufour JM, Hofmann MC, Griswold MD. 2016. The Sertoli cell: one hundred fifty years of beauty and plasticity. Andrology, 4:189-212.

França LR, Nobrega RH, Morais RDVS, Assis LHC, Schulz RW. 2015. Sertoli cell structure and function in anamniote vertebrates. In Griswold, MD (Ed.). Sertoli Cell Biology. Pullman, WA: Elsevier. pp. 469.

França LR, Ogawa T, Avarbock MR, Brinster RL, Russell LD. 1998. Germ cell genotype controls cell cycle during spermatogenesis in the rat. Biol Reprod, 59:1371-1377.

França LR, Silva VA, Chiarini-Garcia H, Garcia SK, Debeljuk L. 2000. Cell proliferation and hormonal changes during postnatal development of the testis in the pig. Biol Reprod, 63:1629-1636.

Gautier A, Bosseboeuf A, Auvray P, Sourdaine P. 2014. Maintenance of potential spermatogonial stem cells in vitro by GDNF treatment in a chondrichthyan model (Scyliorhinus canicula L.). Biol Reprod, 91:91.

Gondos B, Berndston WE. 1993. Postnatal and pubertal development. In Griswold MD, Russell LD (Eds.). The Sertoli Cell. Clearwater, FL: Cache River Press. pp. 115-154.

Gribbins K. 2011. Reptilian spermatogenesis. Spermatogenesis, 1:250-269.

Grier HJ. 1993. Comparative organization of Sertoli cells including the Sertoli cell barrier. In Griswold MD, Russell LD (Eds.). The Sertoli Cell. Clearwater, FL: Cache River Press. pp. 703-740.

Griswold MD. 1998. The central role of Sertoli cells in spermatogenesis. Semin Cell Dev Biol, 9:411-416.

Griswold MD. 2015. Sertoli Cell Biology. Oxford: Elsevier Academic Press. 469p.

Griswold MD. 2016. Spermatogenesis: the commitment to meiosis. Physiol Rev, 96:1-17.

Haverfield JT, Stanton PG, Meachem SJ. 2015. Adult Sertoli cell differentiation status in humans. In Griswold, MD (Ed.). Sertoli Cell Biology. Oxford: Elsevier Academic Press. pp. 409-436.

Hayrabedyan S, Todorova K, Pashova S, Mollova M, Fernández N. 2012. Sertoli cell quiescence - New insights. Am J Reprod Immunol, 68:451-455. 
Hess RA, França LR. 2005. Structure of the Sertoli cell. In Griswold MD, Skinner MK (Eds.). Sertoli Cell Biology. San Diego: Elsevier Academic Press. pp. 19-40.

Hess RA, França LR. 2007. Spermatogenesis and cycle of the seminiferous epithelium. Adv Exp Med Biol, 636:1-15.

Hess RA, Vogl AW. 2015. Sertoli cell anatomy and cytoskeleton. In Griswold, MD (Ed.). Sertoli Cell Biology. Oxford: Elsevier Academic Press. pp. 1-55.

Jannini EA, Ulisse S, D'Armiento M. 1995. Thyroid hormone and male gonadal function. Endocr Rev, 16:443-459.

Johnston DS, Olivas E, DiCandeloro P, Wright WW. 2011. Stage-specific changes in GDNF expression by rat Sertoli cells: a possible regulator of the replication and differentiation of stem spermatogonia. Biol Reprod, 85:763-769.

Johnston DS, Wright WW, Dicandeloro P, Wilson E, Kopf GS, Jelinsky SA. 2008. Stage-specific gene expression is a fundamental characteristic of rat spermatogenic cells and Sertoli cells. Proc Natl Acad Sci USA, 105:8315-8320.

Joyce KL, Porcelli J, Cooke OS. 1993. Neonatal goitrogen treatment increases adult testis size and sperm production in the mouse. J Androl, 14:448-455.

Kerr JB. 1995. Macro, micro, and molecular research on spermatogenesis: the quest to understand its control. Microsc Res Tech, 32:364-384.

Kidder GM, Cyr DG. 2016. Roles of connexins in testis development and spermatogenesis. Semin Cell Dev Biol, 50:22-30.

Kirby JD, Mankar MV, Hardesty D, Kreider DL. 1996. Effects of transient prepubertal 6-N-propyl-2thiouracil treatment on testis development and function in the domestic fowl. Biol Reprod, 55, 910-6.

Klobucar I, Kosec M, Cebulj-Kadunc N, Majdic G. 2003. Postnatal hypothyroidism does not affect prepubertal testis development in boars. Reprod Domest Anim, 38:193-198.

Kulibin AY, Malolina EA. 2016. Only a small population of adult Sertoli cells actively proliferates in culture. Reproduction, 152:271-281.

Lacerda SM, Costa GM, França LR. 2014. Biology and identity of fish spermatogonial stem cell. Gen Comp Endocrinol, 207:56-65.

Lacerda SMSN, Batlouni SR, Silva SBG, Homem CSP, França LR. 2006. Germ cells transplantation in fish: the Nile- tilapia model. Anim Reprod, 3:146-159.

Lara NLM, Avelar GF, Costa GMJ, Lacerda, SMSN, Hess RA, França LR. 2018a. Cell - Cell Interactions - Structural. In Skinner MK (Ed.). Encyclopedia of Reproduction. Academic Press Elsevier. pp. 68-75.

Lara NLM, Costa GMJ, Avelar GF, Lacerda, SMSN, Hess RA, França LR. 2018b. Testis Physiology - Overview and Histology. In Skinner MK (Ed.). Encyclopedia of Reproduction. Academic Press: Elsevier. pp. 105-116.

Lara NLM França LR. 2017. Neonatal hypothyroidism does not increase Sertoli cell proliferation in $\mathrm{iNOS}^{-/}$mice. Reproduction, 154:13-22.

Leal MC, Cardoso ER, Nóbrega RH, Batlouni SR,
Bogerd J, França LR, Schulz RW. 2009. Histological and stereological evaluation of zebrafish (Danio rerio) spermatogenesis with an emphasis on spermatogonial generations. Biol Reprod, 81:177-187.

Leal MC, França LR. 2009. Slow increase of Sertoli cell efficiency and daily sperm production causes delayed establishment of full sexual maturity in the rodent Chinchilla lanigera. Theriogenology, 71:509-518.

Lee NPY, Cheng CY. 2004. Ectoplasmic specialization, a testis-specific cell-cell actin-based adherens junction type: is this a potential target for male contraceptive development? Human reproduction update, 10:349-369.

Lucas TFG, Lazari MFM, Porto CS. 2014a. Differential role of the estrogen receptors ESR1 and ESR2 on the regulation of proteins involved with proliferation and differentiation of Sertoli cells from 15day-old rats. Mol Cell Endocrinol, 382:84-96.

Lucas TFG, Nascimento AR, Pisolato R, Pimenta MT, Lazari MFM, Porto CS. 2014b. Receptors and signaling pathways involved in proliferation and differentiation of Sertoli cells. Spermatogenesis, 4:e28138.

Malolina EA, Kulibin AY. 2017. Rete testis and the adjacent seminiferous tubules during postembryonic development in mice. Russ J Dev Biol, 48:385-392.

Matta SLP, Vilela DAR, Godinho HP, França LR. 2002. The goitrogen 6-n-propyl-2-thiouracil (PTU) given during testis development increases Sertoli and germ cell numbers per cyst in fish: the tilapia (Oreochromis niloticus) model. Endocrinology, 143:970-978.

McClusky LM. 2006.Stage-dependency of apoptosis and blood-testis barrier in the dogfish shark (Squalus acanthias): cadmiuminduced changes as assessed by vital fluorescence techniques. Cell Tissue Res, 325:541-553.

McCoard SA, Wise TH, Lunstra DD, Ford JJ. 2003. Stereological evaluation of Sertoli cell ontogeny during fetal and neonatal life in two diverse breeds of swine. $J$ Endocrinol, 178:395-403.

Meistrich ML, Hess RA. 2013. Assessment of spermatogenesis through staging of seminiferous tubules. Methods Mol Biol, 927:299-307.

Mital P, Hinton BT, Dufour JM. 2011. The bloodtestis and blood-epididymis barriers are more than just their tight junctions. Biol Reprod, 84:851-858.

Morais RD, Nóbrega RH, Gomez-Gonzalez NE, Schmidt R, Bogerd J, França LR, Schulz RW. 2013. Thyroid hormone stimulates the proliferation of Sertoli cells and single type A spermatogonia in adult zebrafish (Danio rerio) testis. Endocrinology, 154:4365-4376.

Murphy CJ, Richburg JH. 2014. Implications of Sertoli cell induced germ cell apoptosis to testicular pathology. Spermatogenesis, 4:e979110.

Nóbrega RH, Batlouni SR, França LR. 2009. An overview of functional and stereological evaluation of spermatogenesis and germ cell transplantation in fish. Fish Physiol Biochem, 35:197-206.

Nykänen M. 1979. Fine structure of the transitional zone of the rat seminiferous tubule, Cell Tissue Res, 198:441-454. 
Oatley JM, Brinster RL. 2012. The germline stem cell niche unit in mammalian testes. Physiol Rev, 92:577595.

Oatley MJ, Racicot KE, Oatley JM. 2011. Sertoli cells dictate spermatogonial stem cell niches in the mouse testis. Biol Reprod, 84:639-645.

Orth JM. 1982. Proliferation of Sertoli cells in fetal and postnatal rats: a quantitative autoradiographic study. Anat Rec, 203:485-492.

Orth JM. 1993. Cell biology of testicular development in the fetus and neonate. In Desjardins $\mathrm{C}$ and Ewing LL (Eds.). Cell and Molecular Biology of the Testis. New York: Oxford University Press. pp. 3-42.

Osman DI. 1978. On the ultrastructure of modified Sertoli cells in the terminal segment of seminiferous tubules in the boar. J Anat, 127:603-613

Pawar HS, Wrobel KH. 1991. Quantitative aspects of water buffalo (Bubalus bubalis) spermatogenesis. Arch Histol Cytol, 54:491-509.

Pelletier RM. 1995. The distribution of connexin 43 is associated with the germ cell differentiation and with the modulation of the Sertoli cell junctional barrier in continual (guinea pig) and seasonal breeders' (mink) testes. J Androl, 16:400-409.

Pointis G, Gilleron J, Carette D, Segretain D. 2010. Physiological and physiopathological aspects of connexins and communicating gap junctions in spermatogenesis. Philos Trans R Soc Lond B Biol Sci, 365:1607-20.

Potter SJ, DeFalco T. 2017. Role of the testis interstitial compartment in spermatogonial stem cell function. Reproduction, 153:R151-R162.

Pudney J. 1993. Comparative cytology of the nonmammalian Sertoli cell. In Russell LD, Griswold MD (Eds.). The Sertoli Cell. Clearwater, FL: Cache River Press. pp. 611-658.

Puglisi R, Montanari M, Chiarella P, Stefanini M, Boitani C. 2004. Regulatory role of BMP2 and BMP7 in spermatogonia and Sertoli cell proliferation in the immature mouse. Eur J Endocrinol, 151:511-520.

Ramaiah M, Wilkinson MF. 2015. MicroRNAs and Sertoli cells. In Griswold MD (Ed.). Sertoli Cell Biology. Oxford: Elsevier Academic Press. pp. 307-332. Regaud C. 1899. Sur la morphologie de la cellule de Sertoli et sur son role dans la spermatogénese chez les mammiféres. C R Assoc Anat, 1:21-31.

Rothbarth K, Kempf T, Juodka B, Glaser T, Stammer H, Werner D. 2001. Intracellular location and nuclear targeting of the Spi-1, Spi-2 and Spi-3 genederived serine protease inhibitors in non-secretory cells. Eur J Cell Biol, 80:341-348.

Russell LD. 1977. Movement of spermatocytes from the basal to the adluminal compartment of the rat testis. Am J Anat, 148:313-328.

Russell LD. 1993a. Form, dimensions, and cytology of mammalian Sertoli cells. In Russell LD, Griswold MD (Eds.). The Sertoli Cell. Clearwater, FL: Cache River Press. pp. 1-37.

Russell LD. 1993b. Morphological and functional evidence for Sertoli-germ cell relationships. In Russell LD, Griswold MD (Eds.). The Sertoli Cell. Clearwater, FL: Cache River Press. pp. 365-390.
Russell LD, Chiarini-Garcia H, Korsmeyer SJ, Knudson CM. 2002. Bax-dependent spermatogonia apoptosis is required for testicular development and spermatogenesis. Biol Reprod, 66:950-958.

Russell LD, Griswold MD. 1993. The Sertoli Cell. Clearwater, FL: Cache River Press. 801p.

Schulz RW, França LR, Lareyre JJ, LeGac F, Chiarini-Garcia H, Nóbrega RH, Miura T. 2010. Spermatogenesis in fish. Gen Comp Endocrinol, 165:390-411.

Schulz RW, Menting S, Bogerd J, Franca LR, Vilela DA, Godinho HP. 2005. Sertoli cell proliferation in the adult testis-evidence from two fish species belonging to different orders. Biol Reprod, 73:891-898.

Schulz RW, van Dijk W, Chaves-Pozo E, GarcíaLópez A, França LR, Bogerd J. 2012. Sertoli cell proliferation in the adult testis is induced by unilateral gonadectomy in African catfish. Gen Comp Endocrinol, 177:160-167.

Sertoli E. 1865. Dell'esistenza di particolari cellule ramificate nei canalicoli seminiferi del testicolo umano. Morgagni, 7:31-40.

Shaha C, Tripathi R, Mishra DP. 2010. Male germ cell apoptosis: regulation and biology. Philos Trans $R$ Soc Lond B Biol Sci, 365:1501-1515.

Sharpe RM. 1988. Bidirectional secretion by the Sertoli cell. Int J Androl, 11:87-91.

Sharpe RM. 1994. Regulation of spermatogenesis. In: Knobil E, Neill J (Eds.). The Physiology of Reproduction. New York: Raven Press. pp. 1363-1434.

Sharpe RM, McKinnell C, Kivlin C, Fisher JS. 2003. Proliferation and functional maturation of Sertoli cells, and their relevance to disorders of testis function in adulthood. Reproduction, 125:769-784.

Shimizu A. 2003. Effect of photoperiod and temperature on gonadal activity and plasma steroid levels in a reared strain of the mummichog (Fundulus heteroclitus) during different phases of its annual reproductive cycle. Gen Comp Endocr, 131:310-324.

Silva Jr VA. 2000. Effects of postnatal hypo and hyperthyroidism on Sertoli cell proliferation and testis function [in Portuguese]. Belo Horizonte, Brazil: Federal University of Minas Gerais. Thesis.

Simon L, Ekman GC, Tyagi G, Hess RA, Murphy KM, Cooke PS. 2007. Common and distinct factors regulate expression of mRNA for ETV5 and GDNF, Sertoli cell proteins essential for spermatogonial stem cell maintenance. Exp Cell Res, 313:3090-3099.

Skinner MK, Griswold MD. 2005. Sertoli Cell Biology. San Diego: Elsevier Academic Press. 494p.

Steger K, Wrobel KH. 1994. Immunohistochemical demonstration of cytoskeletal proteins in the ovine testis during postnatal development. Anat Embryol, 189:521530 .

Tadokoro Y, Yomogida K, Ohta H, Tohda A, Nishimune Y. 2002. Homeostatic regulation of germinal stem cell proliferation by the GDNF/FSH pathway. Mech Dev, 113:29-39.

Tarn CY, Rosenkrans Jr CF, Apple JK, Kirby JD. 1998. Effects of 6N-propyl-2-thiouracil on growth, hormonal profiles, carcass and reproductive traits of boars. Anim Reprod Sci, 50:81-94. 
Tarulli GA, Stanton PG, Meachem SJ. 2012. Is the adult Sertoli cell terminally differentiated? Biol Reprod, 87:13, 1-11.

Tarulli GA, Stanton PG, Meyts ER, Loveland KL, McLachlan RI, Meachem SJ. 2013. A survey of Sertoli cell differentiation in men after gonadotropin suppression and in testicular cancer. Spermatogenesis, 3:e24014.

Tedde G, Montella A, Fiocca D, Delrio AN. 1993. The sertolian epithelium in the testis of men affected by "Sertoli-cell-only syndrome". Ital $J$ Anat Embryol, 98:105-117.

Toppari J, Kangasniemi M, Kaipia A, Mali P, Huhtaniemi I, Parvinen M. 1991. Stage- and cellspecific gene expression and hormone regulation of the seminiferous epithelium. $J$ Electron Microsc Tech, 19:203-214

Tung PS, Fritz IB. 1978. Specific surface antigens on rat pachytene spermatocytes and successive classes of germinal cells. Dev Biol, 64:297-315.

Van Haaster LH, De Jong FH, Docter R, De Rooij DG. 1992. The effect of hypothyroidism on Sertoli cell proliferation and differentiation and hormone levels during testicular development in the rat. Endocrinology, 131:1574-1576.

Van Haaster LH, De Jong FH, Docter R, De Rooij DG. 1993. High neonatal triiodothyronine levels reduce the period of Sertoli cell proliferation and accelerate tubular lumen formation in the rat testis, and increase serum inhibin levels. Endocrinology, 133:755-760.

Vilela DAR, Silva SGB, Peixoto MTD, Godinho HP, França LR. 2003. Spermatogenesis in teleost: insights from the Nile tilapia (Oreochromis niloticus) model. Fish Physiol Biochem, 28:187-190.
Vogl AW, Pfeiffer DC, Redenbach DM, Grove BD. 1993. Sertoli cell cytoskeleton. In Russell LD, Griswold MD (Eds.). The Sertoli Cell. Clearwater, FL: Cache River Press. pp. 39-86.

Vogl AW, Vaid KS, Guttman JA. 2008. The Sertoli cell cytoskeleton. In Cheng CY (Ed.). Molecular mechanisms in spermatogenesis. New York: Springer. pp.186-211.

Vogl AW, Young JS, Du M. 2013. New insights into roles of tubulobulbar complexes in sperm release and turnover of blood-testis barrier. Int Rev Cell Mol Biol, 303:319-355.

Walker WH. 2003a. Molecular mechanisms controlling Sertoli cell proliferation and differentiation. Endocrinology, 144:3719-3721.

Walker WH. 2003b. Nongenomic actions of androgen in Sertoli cells. Curr Top Dev Biol, 56:25-53.

Wong EW, Cheng CY. 2009. Polarity proteins and cell-cell interactions in the testis. Int Rev Cell Mol Biol, 278:309-353.

Wright WW. 2015. Stage-specific gene expression by Sertoli cells. In Griswold MD (Ed.). Sertoli Cell Biology. Oxford: Elsevier Academic Press. pp. 273-306. Yang Q-E, Oatley JM. 2015. Early postnatal interactions between Sertoli and germ cells. In Griswold MD (Ed.). Sertoli Cell Biology. Oxford: Elsevier Academic Press. pp. 81-98.

Ye SJ, Ying L, Ghosh S, França LR, Russell LD. 1993. The Sertoli cell cycle: a re-examination of the structural changes during the cycle of the seminiferous epithelium. Anat Rec, 237:187-198.

Yoshida S. 2016. From cyst to tubule: innovations in vertebrate spermatogenesis. Wiley Interdiscip Rev Dev Biol, 5:119-131. 